\title{
EBSELEN ANALOGUES REDUCE 2-CHLOROETHYL ETHYL SULPHIDE TOXICITY IN A-431 CELLS
}

\author{
Maria A. PINO ${ }^{1,2}$, Magdalena PIETKA-OTTLIK ${ }^{3}$, and Blase BILLACK ${ }^{1}$ \\ Department of Pharmaceutical Sciences, College of Pharmacy and Health Sciences, St. John's University, Jamaica, \\ NY USA ${ }^{1}$, Department of Basic Biomedical Sciences, Touro College of Osteopathic Medicine, Harlem, NY USA ${ }^{2}$, \\ Division of Organic and Pharmaceutical Technology, Faculty of Chemistry, Wroctaw University of Technology, \\ Wroctaw, Poland ${ }^{3}$
}

Received in December 2011

CrossChecked in December 2011

Accepted in September 2012

\begin{abstract}
Vesicants are potent blistering agents. The prototype vesicant is sulphur mustard gas, first used in World War I, which still has no effective antidote. We used a mustard gas surrogate 2-chloroethyl ethyl sulphide (CEES) to study the ability of resveratrol (RES) and pterostilbene (PTS), two well-established stilbene antioxidants, ebselen (EB-1), an organoselenium compound, and three EB-1 analogues (EB-2, EB-3, and EB-4) to reduce CEES toxicity in human epidermoid carcinoma cells (A-431). Following a 24-hour incubation of a toxic concentration of CEES $\left(1000 \mu \mathrm{mol} \mathrm{L}^{-1}\right)$, we used the MTT [3-(4,5-dimethylthiazol2-yl)-2,5-diphenyltetrazolium bromide] test to analyse cell viability. Different concentrations of test antioxidants alone $\left(15 \mu \mathrm{mol} \mathrm{L}^{-1}, 30 \mu \mathrm{mol} \mathrm{L}^{-1}\right.$ or $\left.60 \mu \mathrm{mol} \mathrm{L}^{-1}\right)$ did not decrease cell viability. Treatment with CEES and test antioxidants for $24 \mathrm{~h}$ showed that only EB- 1 and its analogues EB-2, EB-3, and EB-4 but not the stilbene compounds could rescue the cells from death. EB-1 and EB-4 were the most effective at reducing CEES cytotoxicity and did so in a concentration-dependent manner, while EB-2 and EB-3 demonstrated the least protective effect. In summary, the data described herein indicate that organoselenium antioxidants, especially EB-4, may prove useful as countermeasures to blistering agents.
\end{abstract}

KEY WORDS: $C E E S$, cell viability, EB-1, EB-2, EB-3, EB-4, human epidermoid carcinoma cells, MTT test, organoselenium, pterostilbene, resveratrol, vesicant countermeasure

During the First World War, a sulphur mustard compound known as bis(2-chloroethyl)sulfide and commonly referred to as mustard gas was developed into a weapon and has since been used in a number of world conflicts. Mustard gas and its analogues have a vesicant or blistering capacity when applied to skin $(1,2)$. The resulting blisters are slow to heal and pose the risk of secondary infection. Mustard gas also exhibits a wide array of toxicities. From a chemical point of view, vesicants are relatively simple to synthesize and exposure to weapons-grade mustards on the battlefield or in a civilian setting could overload available emergency services (3) and become difficult to manage, since no specific antidote has been developed to control mustard toxicity. Thus, an effective countermeasure to mustard gas toxicity would be beneficial to the public health.

In addition to causing DNA alkylation, mustards also readily bind to cellular thiols; particularly the free thiol group of the cysteine residue within the cellular antioxidant glutathione (GSH). As GSH is neutralised by mustards, the cell becomes increasingly more sensitive to oxidative stress (4). Oxidative stress can lead to cell death when the production of reactive oxygen (ROS) and/or reactive nitrogen oxide species (RNOS) exceeds the capacity of cellular antioxidant defence mechanisms $(5,6)$. In recent years, the idea of using antioxidants to decrease the toxicity of 
vesicants has gained momentum through results obtained from in vivo $(7,8)$ and in vitro studies $(9-12)$. While these antioxidants may serve as effective countermeasures to mustard toxicity in various experimental models, none of them have evolved into an effective therapy to date.

This report describes the results of a study in which several compounds with established or suspected antioxidant activities were tested for ability to reduce the toxicity of a sulphur mustard surrogate in vitro. These compounds, from this point forward designated as the test compounds, were resveratrol (RES), pterostilbene (PTS), ebselen (EB-1), and three EB-1 analogues (EB-2, EB-3 and EB-4) which, although not as extensively studied as the parent compound, exhibit structural features common to organoselenium compounds with antioxidant activity $(13,14)$. Since working with mustard gas poses a significant risk to the investigator and is not commercially available, we used an analogue of mustard gas instead, that is, 2chloroethyl ethyl sulphide (CEES). This compound is commonly referred to as half mustard due to the presence of a single chloroethyl group and forms only monofunctional adducts with DNA. We selected human epidermoid carcinoma cells (A-431) to study the ability of the test compounds to reduce CEES toxicity. This cell line has been used in various in vitro dermatological studies, as it provides an affordable alternative to the use of primary skin cultures $(9,12$, 15-17).

\section{MATERIALS AND METHODS}

\section{Cell line}

A-431 human epidermoid carcinoma cells (ATCC \#CRL-1555) (18) were purchased from the American Type Culture Collection (Manassas, VA, USA).

\section{Treatment compounds}

Unless otherwise indicated, all treatment compounds were purchased from Sigma-Aldrich (St. Louis, MO, USA), as follows: half-mustard (CEES, cat \# 242640), resveratrol (RES, 3,4',5-trihydroxytrans-stilbene, cat \# R5010) and pterostilbene (PTS, 3,5-dimethoxy-4'-hydroxy-trans-stilbene, cat \# P1499). Ebselen (EB-1;2-phenyl-1,2-benzisoselenazol3(2H)-one, cat \# 70530) and ebselen oxide (EB-3, cat \#10012298) were purchased from the Cayman
Chemical Company (Ann Arbor, Michigan, USA). Ebselen analogues (EB-2 and EB-4) were synthesized as described previously (19). The chemical structures of CEES and the compounds tested are shown in Figure 1.

\begin{tabular}{|c|c|}
\hline Compounds & Chemical Structure \\
\hline CEES & \\
\hline RES & \\
\hline PTS & \\
\hline EB-1 & \\
\hline EB-2 & \\
\hline EB-3 & \\
\hline EB-4 & \\
\hline
\end{tabular}

Figure 1 Structure of CEES and of the tested antioxidant compounds

\section{Chemicals and other reagents}

Unless otherwise indicated, all chemicals used in the study were purchased from Sigma-Aldrich (St. Louis, MO, USA) and included dimethylsulphoxide (DMSO, cat \# D8418), 3-(4,5-dimethyl-2-thiazolyl)2,5-diphenyl-2H-tetrazolium bromide (MTT, cat \# M2128), Triton-X100( cat \# T8787), BSA (cat \# A7906), phosphate buffered saline (PBS, cat\# P3813), tris-hydroxymethylaminomethane (TRIS, cat \# 154563), phenol solution (cat \# P4557), chloroform: isoamyl alcohol (cat \#C0549), EDTA (cat \# E0399), agarose (cat \# A9539), glacial acetic acid (cat \# 242853), and glycerol (cat\# G5516). Elutriation buffer (cat \# 19086) was purchased from Qiagen, Inc. (Valencia, CA, USA). Trypan blue dye (cat \# BDH8721-0) was obtained from VWR International (West Chester, PA, USA). Potassium acetate (cat \# 529543), ethidium bromide (cat \# EM- 4410), NaCl (cat \#EM- 7710), and boric acid (cat \# EM-203667) were purchased from EMD Chemicals (Gibbstown, NJ, USA). 


\section{Cell culturing medium}

Cells were grown in tissue culture dishes in Dulbecco's Modified Eagle's Medium (DMEM) containing phenol red, L-glutamine, glucose $4.5 \mathrm{mg} \mathrm{L}^{-1}$, and $10 \%$ heat-inactivated foetal bovine serum (FBS) and were supplemented with $50 \mu \mathrm{g} \mathrm{mL}^{-1}$ of gentamicin (cat \# 15750-060; Invitrogen, Carlsbad, CA, USA). Complete DMEM was obtained by mixing $50 \mathrm{~mL}$ of FBS and $550 \mu \mathrm{L}$ of gentamicin. A-431 skin cells were briefly trypsinised prior to passaging (Invitrogen Corporation, Carlsbad, CA, USA, cat \# 10564). Cells were treated in DMEM containing L-glutamine and glucose, but not phenol red and FBS (clear DMEM) (Invitrogen Corporation, Carlsbad, CA, USA; cat \# 25300-054).

\section{Assays to determine cellular viability}

We mixed $347 \mu$ L of CEES with $9.6 \mathrm{~mL}$ of ethanol to yield a $300 \mathrm{mmol} \mathrm{L}^{-1}$ stock solution and stored it at $4{ }^{\circ} \mathrm{C}$ until needed. RES (14.8 mg) was dissolved in DMSO $(648 \mu \mathrm{L})$ to make a $100 \mathrm{mmol} \mathrm{L}^{-1}$ stock solution. PTS $(208.8 \mathrm{mg}$ ) was dissolved in $8125 \mu \mathrm{L}$ of DMSO and EB-1 (10 mg) was dissolved in $364 \mu \mathrm{L}$ of DMSO to yield $100 \mu \mathrm{mol} \mathrm{L}^{-1}$ solutions. Next, $4.7 \mathrm{mg}$ of EB-2 was dissolved in DMSO $(167 \mu \mathrm{L})$ and gently heated. In addition, $2.9 \mathrm{mg}$ of EB-3 and $6.9 \mathrm{mg}$ EB-4 were dissolved in DMSO $(172.4 \mu \mathrm{L}$ and $250 \mu \mathrm{L}$, respectively) to make a $100 \mathrm{mmol} \mathrm{L}^{-1}$ stock solution of each. Finally, all the test compounds $(100 \mathrm{mmol}$ $\mathrm{L}^{-1}$ ) were dissolved in an appropriate amount of DMSO to make a final stock solution of $60 \mathrm{mmol} \mathrm{L}^{-1}$ and were stored at $-20{ }^{\circ} \mathrm{C}$ until treatment.

MTT reagent was prepared by mixing $0.04 \mathrm{~g}$ of thiazolyl blue tetrazolium bromide powder with $8 \mathrm{~mL}$ of FBS-free, phenol-free DMEM to yield a final concentration of $5 \mathrm{mg} \mathrm{mL}^{-1}$. MTT solubilisation reagent was prepared by mixing $270 \mathrm{~mL}$ of isopropyl alcohol, $30 \mathrm{~mL}$ Triton- $\mathrm{X}$, and $30 \mathrm{~mL}$ of $1 \mathrm{~mol} \mathrm{~L}^{-1} \mathrm{HCl}$ in a glass amber bottle and was stored at room temperature.

A-431 skin cells were seeded into 24 -well plates $\left(1 \times 10^{5}\right.$ cells per well) and treated the next day. Culture medium containing FBS was removed from each well and replaced with $0.5 \mathrm{~mL}$ of FBS- and phenol red-free DMEM containing either 0 (control), $15 \mu \mathrm{mol} \mathrm{L}^{-1}$, $30 \mu \mathrm{mol} \mathrm{L}{ }^{-1}$, or $60 \mu \mathrm{mol} \mathrm{L}^{-1}$ of each test compound. Cells were then incubated in parallel with or without CEES $\left(1000 \mu \mathrm{mol} \mathrm{L}^{-1}\right)$. After $24 \mathrm{~h}$, the MTT viability assay was conducted. All treatments were performed in triplicate wells for each test compound, and all experiments were performed a minimum of three times each.

Control wells were supplemented with $0.1 \%$ of DMSO. This concentration of vehicle was neither toxic nor inhibitory in the MTT assay (data not shown).

The MTT assay measures the conversion of 3-(4,5dimethyl-2-thiazolyl)-2,5-diphenyl-2H-tetrazolium bromide (MTT) into a coloured product in living cells. To determine the viability of cells, the MTT assay was performed as described by Mosmann (20), with the incubation time of the MTT reagent being modified as described by Shah et al. (21). To $500 \mu \mathrm{L}$ of culture medium we added $50 \mu \mathrm{L}$ of MTT and let it incubate at $37^{\circ} \mathrm{C}$ for $1 \mathrm{~h}$. Next we added $550 \mu \mathrm{L}$ of MTT solubilisation reagent, mixed the wells, and let it incubate for another $10 \mathrm{~min}$, still at $37^{\circ} \mathrm{C}$. The optical density of this purple formazan product was then measured spectrophotometrically in a glass cuvette at $570 \mathrm{~nm}$. The MTT reagent did not react with any of the test compounds at the concentrations used in the absence of cells (data not shown), which validates its use for cell viability studies.

To determine whether or not EB-1 could reduce CEES toxicity in a viability assay not related to the MTT assay, A-431 cells were plated in 6-well plates ( $1 \times 10^{6}$ cells per well). The following day, culture medium was removed from triplicate wells and replaced with FBS and phenol red-free DMEM containing either the DMSO vehicle $(0.1 \%)$ or CEES $\left(1000 \mu \mathrm{mol} \mathrm{L}^{-1}\right)$ in the presence or absence of EB-1 $\left(15 \mu \mathrm{mol} \mathrm{L}^{-1}, 30 \mu \mathrm{mol} \mathrm{L}-1\right.$ or $\left.60 \mu \mathrm{mol} \mathrm{L}-1\right)$. After $24 \mathrm{~h}$, culture medium was removed from all wells and the wells were washed once with PBS. Next, $500 \mu \mathrm{L}$ of trypsin was added to each well and incubated for 10 min at $37^{\circ} \mathrm{C}$. Cells were collected in a microfuge tube and spun in a table top centrifuge at $1957 \times \mathrm{g}$ for 5 $\mathrm{min}$. The supernatant was removed and $500 \mu \mathrm{L}$ of FBS and phenol red-free DMEM was used to re-suspend the cell pellet. Next, $50 \mu \mathrm{L}$ of the re-suspended sample was added to an equal volume of trypan blue in a new microfuge tube. Finally, $10 \mu \mathrm{L}$ of this combined solution was applied to a haemocytometer, which was inspected with a standard light microscope at 20x magnification. Cells without the dye were counted as viable and the number of viable cells per treatment was evaluated.

\section{CEES-induced DNA fragmentation}

A-431 skin cells were grown to $90 \%$ confluency in complete DMEM in 6-well plates $\left(1 \times 10^{6}\right.$ cells per 
well). The next day, the culture medium was removed and separate wells were incubated with $2 \mathrm{~mL}$ of FBSand phenol-red free DMEM containing different concentrations of CEES $(0,250,500,1000,1500$, and 2000) $\mu \mathrm{mol} \mathrm{L}{ }^{-1}$. These plates were then incubated at $37^{\circ} \mathrm{C}$ for $16 \mathrm{~h}$ to $18 \mathrm{~h}$. DNA fragments were then isolated and analysed according to the method reported by our lab previously (12).

\section{Log $\mathrm{P}$ determination for EB-1 and its analogues}

$\log P$, or the logarithmic partition coefficient of 1-octanol/water, is a critical tool in the determination of drug membrane permeability. This value is used to estimate properties such as absorption, metabolism, and bioavailability (22). It is worth noting that all log $P$ values for the organoselenium compounds reported in the Results section were obtained using the Molinspiration Property Calculation Service (www. molinspiration.com) and were not experimentally determined.

\section{Statistical analysis}

All experiments were carried out in triplicate, with the results being reported as the mean \pm standard error of the mean from at least three representative experiments. Statistical comparisons were made using either Student's $t$-test (for comparison between two groups) or one-way ANOVA with Neumann-Keuls post hoc test (for comparison across multiple groups) using GraphPad Prism 4.0 ${ }^{\circledR}$ software (GraphPad Software, Inc., San Diego, CA, USA). Differences were considered to be significant at $p<0.05$.

\section{RESULTS}

\section{CEES cytotoxicity in A-431 cells}

At a CEES concentration of $1000 \mu \mathrm{mol} \mathrm{L}^{-1}$, the MTT assay found $\sim 7 \%$ of the cells viable (Table 1 ), whereas the trypan blue dye exclusion method found $\sim 14 \%$ of the cells viable (Table 2). Based on this observation, and to ensure a robust toxicity, MTT viability studies with CEES were performed at a cell density of $1 \times 10^{5}$ cells per well and a concentration of $1000 \mu \mathrm{mol} \mathrm{L}{ }^{-1}$.

\section{CEES-induced DNA fragmentation}

DNA fragments from control and CEES-treated cells $\left[(250,500,1000,1500\right.$ or 2000$\left.) \mu \mathrm{mol} \mathrm{L}^{-1}\right]$ were isolated and extracted using phenol/chloroform, treated with RNase, and analysed using agarose gel electrophoresis. CEES caused a concentrationdependent increase in DNA fragmentation, with the highest fragmentation patterns occurring at $1500 \mu \mathrm{mol} \mathrm{L}^{-1}$ and $2000 \mu \mathrm{mol} \mathrm{L}{ }^{-1} \mathrm{CEES}$ concentrations (Figure 2).

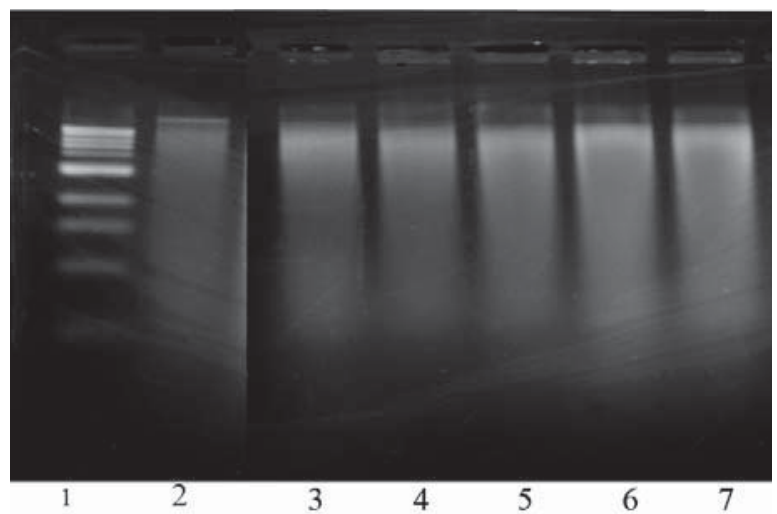

Figure 2 DNA fragmentation in A-431 skin cells resulting from treatment with CEES. Lane 1, DNA $1 \mathrm{~kb}$ marker; lane 2, control; lane 3, $250 \mu \mathrm{mol} \mathrm{L} \mathrm{L}^{-1}$ of CEES; lane 4, $500 \mu \mathrm{mol} \mathrm{L} L^{-1}$ of CEES; lane 5, $1000 \mu \mathrm{mol} \mathrm{L} L^{-1}$ of CEES; lane 6, $1500 \mu \mathrm{mol} \mathrm{L} L^{-1}$ of CEES; lane 7, $2000 \mu \mathrm{mol} \mathrm{L} L^{-1}$ of CEES

\section{Test compounds to counteract the toxicity of CEES}

RES is a naturally occurring stilbene and antioxidant and is polyphenolic in nature (Figure 1). When administered alone, RES was not toxic to the skin cells at any of the test concentrations at $24 \mathrm{~h}$ (Table 1). When administered in combination with CEES, RES did not rescue the cells from death (Table 1). Similar data were obtained for PTS (Table 1).

In contrast, EB-1 exhibited a concentrationdependent increase in survival reaching about $67 \%$ viability at $60 \mu \mathrm{mol} \mathrm{L}{ }^{-1}$ (Table 1). Only the lowest concentration showed no significant increase in viability. In addition, EB-1 alone exhibited no toxicity to the skin cells at $24 \mathrm{~h}$; moreover, at its highest concentration EB-1 significantly increased cell viability $(p<0.001)$ compared to vehicle-treated cells (Table 1).

EB-2 significantly increased MTT activity at $60 \mu \mathrm{mol} \mathrm{L}-1(\sim 10 \%)$ in the absence of CEES cotreatment. In addition, only the $60 \mu \mathrm{mol} \mathrm{L}^{-1}$ concentration of EB-2 provided significant $(p<0.001)$ protection against CEES (Table 1).

EB-3 alone significantly increased A-431 cell viability across the range of test concentrations, but in terms of protection against CEES, only the highest concentration was significantly effective (Table 1). 
Table 1 Effects of selected test compounds on the cytotoxicity of CEES in A-431 skin cells, as determined by the MTT viability assay

\begin{tabular}{|c|c|c|}
\hline \multirow[t]{2}{*}{ Treatment $^{\mathrm{a}}$} & \multicolumn{2}{|c|}{ Viability / \% ${ }^{b}$} \\
\hline & Untreated $^{c}$ & CEES-treated $^{\mathrm{d}}$ \\
\hline Control & 100 & $6.73 \pm 1.06$ \\
\hline \multicolumn{3}{|l|}{$\underline{\mathrm{RES}}$} \\
\hline $\operatorname{RES}\left(15 \mu \mathrm{mol} \mathrm{L}{ }^{-1}\right)$ & $102.00 \pm 2.01$ & $7.56 \pm 0.38$ \\
\hline $\operatorname{RES}\left(30 \mu \mathrm{mol} \mathrm{L}{ }^{-1}\right)$ & $96.60 \pm 0.99$ & $7.16 \pm 0.20$ \\
\hline $\operatorname{RES}\left(60 \mu \mathrm{mol} \mathrm{L}{ }^{-1}\right)$ & $100.60 \pm 3.45$ & $8.27 \pm 0.05$ \\
\hline \multicolumn{3}{|l|}{ PTS } \\
\hline PTS $\left(15 \mu \mathrm{mol} \mathrm{L}^{-1}\right)$ & $98.75 \pm 3.72$ & $3.64 \pm 0.52$ \\
\hline PTS $\left(30 \mu \mathrm{mol} \mathrm{L}^{-1}\right)$ & $96.30 \pm 3.10$ & $3.64 \pm 0.32$ \\
\hline PTS $\left(60 \mu \mathrm{mol} \mathrm{L}^{-1}\right)$ & $92.87 \pm 5.72$ & $3.95 \pm 0.19$ \\
\hline \multicolumn{3}{|l|}{ EB-1 } \\
\hline EB-1 $\left(15 \mu \mathrm{mol} \mathrm{L}^{-1}\right)$ & $96.38 \pm 1.24$ & $17.42 \pm 0.89$ \\
\hline EB-1 $\left(30 \mu \mathrm{mol} \mathrm{L}^{-1}\right)$ & $89.01 \pm 0.94$ & $22.63 \pm 1.71^{\wedge}$ \\
\hline EB-1 $\left(60 \mu \mathrm{mol} \mathrm{L}^{-1}\right)$ & $110.70 \pm 4.40^{* * *}$ & $66.90 \pm 2.33^{\wedge \wedge \wedge}$ \\
\hline \multicolumn{3}{|l|}{ EB-2 } \\
\hline EB-2 $\left(15 \mu \mathrm{mol} \mathrm{L}^{-1}\right)$ & $101.20 \pm 0.91$ & $3.50 \pm 1.03$ \\
\hline EB-2 $\left(30 \mu \mathrm{mol} \mathrm{L}^{-1}\right)$ & $105.10 \pm 0.67$ & $3.90 \pm 0.00$ \\
\hline EB-2 $\left(60 \mu \mathrm{mol} \mathrm{L}^{-1}\right)$ & $109.60 \pm 1.16^{* * *}$ & $11.93 \pm 0.47^{\wedge \wedge \wedge}$ \\
\hline \multicolumn{3}{|l|}{ EB-3 } \\
\hline EB-3 $\left(15 \mu \mathrm{mol} \mathrm{L}^{-1}\right)$ & $113.80 \pm 1.26^{*}$ & $10.43 \pm 0.47$ \\
\hline EB-3 $\left(30 \mu \mathrm{mol} \mathrm{L}^{-1}\right)$ & $140.90 \pm 3.00 * * *$ & $10.62 \pm 0.74$ \\
\hline EB-3 $\left(60 \mu \mathrm{mol} \mathrm{L}^{-1}\right)$ & $149.60 \pm 6.06 * * *$ & $20.17 \pm 0.80^{\wedge \wedge \wedge}$ \\
\hline \multicolumn{3}{|l|}{ EB-4 } \\
\hline EB-4 $\left(15 \mu \mathrm{mol} \mathrm{L}^{-1}\right)$ & $118.00 \pm 3.24 * *$ & $15.17 \pm 0.33^{\wedge}$ \\
\hline EB-4 $\left(30 \mu \mathrm{mol} \mathrm{L}^{-1}\right)$ & $113.70 \pm 0.67 * *$ & $36.06 \pm 2.73^{\wedge \wedge \wedge}$ \\
\hline EB-4 $\left(60 \mu \mathrm{mol} \mathrm{L}^{-1}\right)$ & $123.00 \pm 0.77 * * *$ & $82.31 \pm 3.59^{\wedge \wedge \wedge}$ \\
\hline
\end{tabular}

${ }^{a}$ All cells were cultured for $24 \mathrm{~h}$ in the absence or presence of CEES

${ }^{b}$ Values represent the mean \pm standard error of the mean from three independent experiments

' Significantly different from untreated control cells (vehicle) at ${ }^{*} \mathrm{p}<0.05,{ }^{*} \mathrm{p}<0.01$ or ${ }^{* * *} \mathrm{p}<0.001$ by Student's t-test and ANOVA

${ }^{d}$ Significantly different from CEES-treated control cells at $\hat{\mathrm{p}}<0.05 \mathrm{or}^{\mathrm{m}} \mathrm{p}<0.001$ by Student's t-test and ANOVA

EB-4 in turn showed an $18 \%$ to $23 \%$ increase in cell viability when given alone, and in combination with CEES it showed significant protection at all three concentrations (Table 1).

In summary, all of the EB analogues showed some degree of action against CEES cytotoxicity in A-431 skin cells, but EB-4 showed the highest cytoprotective potential.

The trypan blue dye exclusion method confirmed EB-1 efficiency against CEES toxicity without significantly increasing cell viability when given alone (Table 2). The data obtained with the trypan blue dye exclusion assay showed higher standard errors than data obtained with the MTT assay, which may be attributed to the extensive sample handling required for the trypan assay and the difficulty to distinguish which cells are truly excluding the dye, as some cells appear light blue under the microscope and confound scoring.

$\log P$ values were 2.92 for EB-1, 2.10 for EB-2, 2.88 for EB-3, and 2.44 for EB-4. We established no relationship between lipophilicity, as indicated by log $P$ values, and protection against CEES; however, a more extensive analysis of lipophilicity and countermeasure effectiveness is warranted before any conclusions are drawn. 
Table 2 Effect of EB-1 on the cytotoxicity of CEES in A-431 skin cells, as determined by the trypan blue dye exclusion assay

\begin{tabular}{lcc}
\hline Treatment $^{\mathbf{a}}$ & \multicolumn{2}{c}{${\text { Viability / } \mathbf{o}^{\mathbf{b}}}$} \\
\hline & Untreated & CEES-treated $^{\mathbf{c}}$ \\
\hline EB-1 & 100 & $13.46 \pm 5.52$ \\
\hline Control & $117.30 \pm 8.99$ & $5.89 \pm 2.55$ \\
\hline EB-1 $\left(15 \mu \mathrm{mol} \mathrm{L}^{-1}\right)$ & $71.90 \pm 8.19$ & $45.55 \pm 7.03^{*}$ \\
\hline EB-1 $\left(30 \mu \mathrm{mol} \mathrm{L}^{-1}\right)$ & $76.96 \pm 13.14$ & $39.35 \pm 11.51^{*}$ \\
\hline EB-1 $\left(60 \mu \mathrm{mol} \mathrm{L}^{-1}\right)$ &
\end{tabular}

a All cells were cultured for $24 \mathrm{~h}$ in the absence or presence of CEES

${ }^{b}$ Values represent the mean \pm standard error of the mean from three independent experiments

c Significantly different from CEES- treated control cells at ${ }^{*} p<0.05$ by Student's t-test and ANOVA

\section{DISCUSSION}

It has been nearly one hundred years since mustards were first used as chemical warfare agents, yet an effective medical countermeasure is still sought after $(23,24)$. The cellular mechanisms involved in mustard toxicity are well established and include oxidative stress, DNA damage, and the overactivation of PARP$1(5,25,26)$. The goal of the present research was to determine if the selected test compounds could reduce the toxicity of a sulphur mustard surrogate in vitro. The toxicant used in our studies, CEES, is a monofunctional alkylating agent with vesicant activity in vivo. CEES has been utilised by other laboratories to mimic the effects induced by mustard gas $(27,28)$. The test compounds we used included established antioxidants (RES, PTS and EB-1) and three less studied organoselenium agents (EB-2, EB-3, and EB4) bearing structural similarity to EB-1.

A-431 human epidermoid carcinoma cells are an inexpensive and easy alternative to using primary skin cell cultures $(9,12,15,16)$. An important limitation with this cell line is that it is tumour-derived and expresses a mutant p53 protein $(29,30)$. It is therefore possible that these cells respond differently to mustards than normal skin cells would, and this possibility should not be overlooked. In addition, A-431 cells exposed to mustards in vitro are unable to mimic the response of normal skin tissue to mustard exposure, which becomes injured and forms fluid-filled blisters. In spite of these limitations, the A-431 cells make an important screening tool for potential countermeasures to mustards that can be tested in vivo.

We observed that RES and PTS exhibited no propensity to protect A-431 skin cells from mustard toxicity. RES has been found in at least one in vivo study to protect the lungs from mustard injury (8). This discrepancy may be due to the cell type tested here or to not having used a high enough concentration of the stilbene. The latter however is unlikely, as Radkar et al. (17) found that RES exhibited toxicity in the same cell line with an $\mathrm{LC}_{50}$ of $\sim 60 \mu \mathrm{mol} \mathrm{L}^{-1}$. PTS was also unable to reduce or prevent mustard toxicity in A-431 cells, in contrast to Pereko et al. (31), who found it effective in reducing extracellular reactive oxygen species.

We obtained the best anti-mustard effects with organoseleniums. These compounds contain at least one carbon-selenium bond and are not to be confused with inorganic selenium, which is a trace element in the human diet and has been studied extensively against cancer, immunity and infectious/inflammatory diseases $(19,32)$. Whereas the prototype organoselenium compound EB-1 has already been reported to protect A-431 skin cells from CEES toxicity (12), the ability of the related compounds EB-2, EB-3, and EB-4 to do so has not been studied so far to the best of our knowledge. The reason why we turned to organoselenium analogues as potential countermeasures to CEES toxicity lies in certain limitations of EB-1. For one, EB-1 binds strongly to plasma proteins when administered intravenously and can not reach the cell in the albumin-bound state. It takes thiol-containing reducing agents to free EB-1 to bind to membraneassociated proteins (33). Moreover, the antiinflammatory activity of EB-1 is not likely to be involved in the protection against mustard toxicity observed in this study because like other in vitro models, A-431 skin cells do not possess a vasculature, connective tissue, or immune cells. As EB-1 highly reacts with protein thiols, its in vitro inhibitory activity may be related to nonspecific protein interactions (34). Lastly, EB-1 may inhibit the oxidative burst mechanism used by neutrophils and macrophages during an inflammatory response. The idea that EB-1 can exert an immunosuppressive effect in vivo has been explored 
previously (35). A similar adverse effect on the immune system is known to be induced by mustard agents. Thus, the combined effect of mustard and EB1 on immunity may delay healing in the afflicted patient.

In the present study, all three EB-1 analogues reduced CEES toxicity in A-431 cells, with EB-4 exhibiting the highest degree of protection. Masumoto and Sies (36) suggest that EB-3 may be converted to EB-1 in the presence of intracellular glutathione, but our data do not strongly support this hypothesis, as we would have observed a higher degree of cytoprotection by EB-3 if it had been converted to EB-1. Further investigation is required to determine whether EB-3 can serve as an EB-1 prodrug or if it exerts unique anti-mustard activity.

It is worth noting that we established no relationship between anti-mustard action of the organoselenium compounds tested here and hydrophobicity, as measured by $\log P$. In an attempt to take advantage of the antioxidant potential of EB-1 while minimizing its pharmacological shortcomings, numerous analogues of EB-1, including those studied in this work, have been synthesised, with various structural substitutions $(19,37,38)$. Alterations to hydrophilicity have been introduced to increase water solubility and bioavailability of EB-1, which may be even more suitable for in vivo applications (39). Hopefully these new EB-1 analogues will be more efficient in an animal model, while maintaining the potency equivalent to or greater than EB-1.

It is wise to exercise caution when interpreting the data obtained using selenium compounds in MTT assays. A recent study by Olm et al. (40) indicated that selenite toxicity in cancer cells depended on extracellular reduction by thiols such as cysteine. In our study, the test compounds did not reduce MTT reagent in a cell free system at concentrations up to and including $60 \mu \mathrm{mol} \mathrm{L}^{-1}$ (data not shown). Even so, these compounds may affect extracellular thiol levels. If they do, our in vitro system could reduce MTT reagent, produce false positive results, and give the appearance of protection. This may to some extent explain why cells treated with the organoselenium test compounds alone all exhibited higher viability at the highest concentrations than vehicle-treated control cells. Future studies should inquire whether the increased viability observed in the absence of CEES for EB-1 and its analogues may be due to an increase in extracellular thiols.
One reason why MTT experiments were carried out in a culture medium lacking FBS was to minimise any interference from FBS components such as albumin (41). Even though we did not assess the effects of EB-1 on extracellular redox, Schroterova et al. (42) found that MTT assays provide a reliable measure of cell viability in colon cancer cells exposed to diverse selenium-containing compounds at concentrations up to $256 \mu \mathrm{mol} \mathrm{L}{ }^{-1}$.

We also ran the trypan blue dye exclusion to determine if a non-mitochondrial based assay can measure cytoprotection of organoselenium compounds such as EB-1 against CEES. Although it confirmed that EB-1 protected against CEES, viability of cells treated with EB-1 alone did not increase compared to vehicle-treated controls. The reason is unclear but may be related to low level thiol secretion from organoselenium-treated skin cells. Nonetheless, both viability assays showed that EB-1 protected A-431 skin cells from CEES toxicity.

Although our present study did not determine the mechanism of protection by the organoselenium compounds against CEES toxicity, Kim et al. (43) have suggested that EB-1 activates nuclear transcription via Nrf2. This in turn increases the expression of many phase II enzymes such as heme oxygenase (HO-1), $\mathrm{NAD}(\mathrm{P}) \mathrm{H}$ :quinone oxidoreductase, and gammaglutamylcysteine synthetase (gamma-GCS), which act against oxidants. Knocking down $\mathrm{Nrf} 2$ in the A431 cells with siRNA would likely abolish the protective effects of EB-1 and its analogues, and future studies may be looking in that direction.

EB-1 is also known to possess a glutathione peroxidase-like activity (44), and this mechanism of protection cannot be ruled out for EB-1 and its analogues.

In summary, EB-1 and its analogues show a potential against mustard toxicity. Previous studies demonstrated the effectiveness of EB-1 in vitro $(9,10$, $12)$, this study is the first to propose novel organoselenium compounds (EB-2, EB-3, and EB-4) as agents against mustard toxicity. EB-4 showed the greatest degree of protection against CEES-induced toxicity of all the compounds in this class. Our future studies will investigate whether organoselenium analogues of EB-1 are more efficient in an animal model in comparison with other pharmaceuticals such as topical steroids. We will also look into the mechanisms of protection that these organoselenium compounds provide against CEES toxicity. 


\section{Acknowledgements}

This work was funded by the Department of Pharmaceutical Sciences (St. John's University). The authors are extremely grateful to Anju Lulla (doctoral candidate, St. John's University), Oleksiy Sparavalo (masters candidate, St John's University) and Dr Jacek Młochowski (Professor Emeritus, Wrocław University of Technology) for interesting discussions pertaining to this work. We also thank Dr Cesar Lau-Cam (Professor, St. John's University) for his critical evaluation of the manuscript.

\section{Conflicts of interest}

The authors report no conflicts of interest.

\section{REFERENCES}

1. Le HQ, Knudsen SJ. Exposure to a First World War blistering agent. Emerg Med J 2006;23:296-9.

2. Schmidt A, Bölck B, Jedig M, Steinritz D, Balszuweit F, Kehe K, Bloch W. Nitrogen mustard (Chlorambucil) has a negative influence on early vascular development. Toxicology 2009;263:32-40.

3. Agency for Toxic Substances and Disease Registry (ATSDR). Toxicological profile for sulfur mustards. Atlanta (GA): US Department of Health and Human Services, Public Health Service; 2007.

4. Gross CL, Innace JK, Hovatter RC, Meier HL, Smith WJ. Biochemical manipulation of intracellular glutathione levels influences cytotoxicity to isolated human lymphocytes by sulfur mustard. Cell Biol Toxicol 1993;9:259-67.

5. Korkmaz A, Yaren H, Topal T, Oter S. Molecular targets against mustard toxicity: implication of cell surface receptors, peroxynitrite production, and PARP activation. Arch Toxicol 2006;80:662-70.

6. Paromov V, Qui M, Yang H, Smith M, Stone WL. The influence of $\mathrm{N}$-acetyl-L-cysteine on oxidative stress and nitric oxide synthesis in stimulated macrophages treated with a mustard gas analogue. BMC Cell Biol 2008;9:33. doi:10.1186/1471-2121-9-33

7. Ucar M, Korkmaz A, Reiter RJ, Yaren H, oter S, Kurt B, Topal T. Melatonin alleviates lung damage induced by the chemical warfare agent nitrogen mustard. Toxicol Lett 2007;173:124-31.

8. McClintock SD, Hoesel LM, Das SK, Till GO, Neff T, Kunkel RG, Smith mg, Ward PA. Attenuation of half sulfur mustard gas-induced acute lung injury in rats. J Appl Toxicol 2006;26:126-31.

9. Hardej D, Billack B. Ebselen protects brain, skin, lung, and blood cells from mechlorethamine toxicity. Toxicol Ind Health 2007;23:209-21.

10. Holl V, Coelho D, Silbernagel L, Keyser JF, Waltzinger C, Dufour P, Bischoff PL. Prevention of nitrogen mustardinduced apoptosis in normal and transformed lymphocytes by ebselen. Biochem Pharmacol 2000;60:1565-77.
11. Khan S, Ramwani JJ, O'Brien PJ. Hepatocyte toxicity of mechlorethamine and other alkylating anticancer drugs. Role of lipid peroxidation. Biochem Pharmacol 1992;43:19637.

12. Pino MA, Billack B. Reduction of vesicant toxicity by butylated hydroxyanisole in A-431 skin cells. Cutan Ocul Toxicol 2008;27:161-72.

13. Mugesh G, du Mont W, Sies H. Chemistry of biologically important synthetic organoselenium compounds. Chem Rev 2001;101:2125-79.

14. Bhabak K, Mugesh G. Functional mimics of glutathione peroxidase: bioinspired synthetic antioxidants. Acc Chem Res 2010;43:1408-19.

15. Kanda N, Watanabe S. Cyclooxygenase-2 inhibitor enhances whereas prostaglandin E2 inhibits the production of interferon-induced protein of $10 \mathrm{kDa}$ in epidermoid carcinoma A431. J Invest Dermatol 2002;119:1080-9.

16. Lazarova Z, Domloge-Hultsch N, Yancey KB. Epiligrin is decreased in papulonodular basal cell carcinoma tumor nest basement membranes and the extracellular matrix of transformed human epithelial cells. Exp Dermatol 1995;4:121-

17. Radkar V, Hardej D, Lau-Cam C, Billack B. Evaluation of resveratrol and piceatannol cytoxicity in macrophages, $\mathrm{T}$ cells, and skin cells. Arh Hig Rada Toksikol 2007;58:292304.

18. Giard DJ, Aaronson SA, Todaro GJ, Arnstein P, Kersey JH, Dosik H, Parks WP. In vitro cultivation of human tumors: establishment of cell lines derived from a series of solid tumors. J Natl Cancer Inst 1973;51:1417-23.

19. Wójtowicz H, Kloc K, Maliszewska I, Młochowski J, Pietka M, Piasecki E. Azaanalogues of ebselen as antimicrobial and antiviral agents: synthesis and properties. Farmaco 2004;59:863-8.

20. Mosmann T. Rapid colorimetric assay for cellular growth and survival: application to proliferation and cytotoxicity assays. J Immunol Methods 1983;65:55-63.

21. Shah SJ, Sylvester PW. Gamma-tocotrienol inhibits neoplastic mammary epithelial cell proliferation by decreasing Akt and nuclear factor kappaB activity. Exp Biol Med (Maywood) 2005;230:235-41.

22. Ghose AK, Viswanadhan VN, Wendoloski JJ. Prediction of hydrophobic (Lipophilic) properties of small organic molecules using fragmental methods: an analysis of ALOGP and CLOGP methods. J Phys Chem A 1998;102:3762-72.

23. Graham JS, Stevenson RS, Mitcheltree LW, Hamilton TA, Deckert RR, Lee RB, Schiavetta AM. Medical management of cutaneous sulfur mustard injuries. Toxicology 2009;263:4758.

24. Saladi RN, Smith E, Persaud AN. Mustard: a potential agent of chemical warfare and terrorism. Clin Exp Dermatol 2006;31:1-5.

25. Bhat KR, Benton BJ, Rosenthal DS, Smulson ME, Ray R. Role of poly(ADP-ribose) polymerase (PARP) in DNA repair in sulfur mustard-exposed normal human epidermal keratinocytes (NHEK). J Appl Toxicol 2000;20(Suppl 1): S13-7.

26. Kehe K, Balszuweit F, Steinritz D, Thiermann H. Molecular toxicology of sulfur mustard-induced cutaneous inflammation and blistering. Toxicology 2009;263:12-9.

27. Gordon MK, Desantis A, Deshmukh M, Lacey CJ, Hahn RA, Beloni J, Anumolu SS, Schlager JJ, Gallo MA, Gerecke DR, 
Heindel ND, Svoboda KK, Babin MC, Sinko PJ. Doxycycline hydrogels as a potential therapy for ocular vesicant injury. J Ocul Pharmacol Ther 2010;26:407-19.

28. Jain AK, Tewari-Singh $\mathrm{N}, \mathrm{Gu} \mathrm{M}$, Inturi S, White CW, Agarwal R. Sulfur mustard analog, 2-chloroethyl ethyl sulfide-induced skin injury involves DNA damage and induction of inflammatory mediators, in part via oxidative stress, in SKH-1 hairless mouse skin. Toxicol Lett 2011;205:293-301.

29. Giocanti N, Hennequin C, Rouillard D, Defrance R, Favaudon V. Additive interaction of gefitinib ('Iressa', ZD1839) and ionising radiation in human tumour cells in vitro. Br J Cancer 2004;91:2026-33.

30. Reiss M, Brash DE, Muñoz-Antonia T, Simon JA, Ziegler A, Vellucci VF, Zhou ZL. Status of the p53 tumor suppressor gene in human squamous carcinoma cell lines. Oncol Res 1992;4:349-57.

31. Pereko T, Janncinova V, Drabikova K, Nosal R, Harmatha J. Structure-efficiency relationship in derivatives of stilbene. Comparison of resveratrol, pinosylvin and pterostilbene. Neuro Endocrinol Lett 2008;29:802-5.

32. Tripathi DN, Jena GB. Ebselen attenuates cyclophosphamideinduced oxidative stress and DNA damage in mice. Free Radic Res 2008;42:966-77.

33. Wagner G, Schuch G, Akerboom TP, Sies H. Transport of ebselen in plasma and its transfer to binding sites in the hepatocyte. Biochem Pharmacol 1994;48:1137-44.

34. Sies H, Cadenas E. Oxidative stress: damage to intact cells and organs. Philos Trans R Soc Lond B Biol Sci 1985;311:61731.

35. Nozawa R, Arai M, Kuruto R, Motohashi T, Masayasu H. Susceptibility of mice to bacterial and fungal infections after intragastric administration of ebselen. J Pharm Pharmacol 1996;8:64-7.
36. Masumoto H, Sies H. The reaction of ebselen with peroxynitrite. Chem Res Toxicol 1996;9:262-7.

37. Bien M, Blaszczyk B, Kalinowska K, mLochowski J, Inglot AD. Anitfungal activity of 2-(4-chlorophenyl)-1.2 benzisoselenazol-3(2H)-one, the analog of Ebselen. Arch Immunol Ther Exp (Warsz)1999;47:185-93.

38. Wojtowicz H, Chojnacka M, mLochowski J, Palus J, Syper L, Hudcova D. Functionalized alkyl and aryl diselenides as antimicrobial and antiviral agents: synthesis and properties. Il Farmaco 2003;58:1235-42.

39. Pietka-Ottlik M, Wojtowicz-Mlochowska H, Kolodziejczyk K, Piasecki E, mLochowski J. New organoselenium compounds active against pathogenic bacteria, fungi and viruses, Chem Pharm Bull (Tokyo) 2008;56:1423-7.

40. Olm E, Jönsson-Videsäter K, Ribera-Cortada I, Fernandes AP, Eriksson LC, Lehmann S, Rundlöf AK, Paul C, Björnstedt M. Selenite is a potent cytotoxic agent for human primary AML cells. Cancer Lett 2009;282:116-23.

41. Funk D, Schrenk HH, Frei E. Serum albumin leads to falsepositive results in the XTT and the MTT assay. Biotechniques 2007;43:178-86.

42. Schröterová L, Králová V, Vorácová A, Hasková P, Rudolf E, Cervinka M. Antiproliferative effects of selenium compounds in colon cancer cells: comparison of different cytotoxicity assays. Toxicol In Vitro 2009;23:1406-11.

43. Kim SJ, Park C, Han AL, Youn MJ, Lee JH, Kim Y, Kim ES, Kim HJ, Kim JK, Lee HK, Chung SY, So H, Park R. Ebselen attenuates cisplatin-induced ROS generation through Nrf2 activation in auditory cells. Hear Res 2009;251:70-82.

44. Ursini F, Bindoli A. The role of selenium peroxidases in the protection against oxidative damage of membranes. Chem Phys Lipids 1987;44:255-76. 


\section{Sažetak}

ANALOZI EPSELENA SMANJUJU TOKSIČNOST 2-KLOROETIL ETILNOG SULFIDA U A-431STANICAMA

Plikavci izazivaju izražene mjehuriće na koži. Najpoznatiji je svakako sumporni iperit, koji se prvi put uporabio u 1. svjetskom ratu i do današnjega dana nema djelotvornog protuotrova. U ispitivanju smo rabili zamjenu za iperit, 2-kloroetil etilni sulfid (CEES) da bismo testirali sposobnost resveratrola (RES) i pterostilbena (PTS), dvaju poznatih stilbenskih antioksidansa, organoselenijeva spoja epselena (EB-1) te njegovih triju analoga (EB-2, EB-3 i EB-4) da smanji toksičnost CEES-a u humanih stanica epidermoidnog karcinoma (A-431). Vijabilnost stanica testirali smo s pomoću 3-(4,5-dimetiltiazol-2-il)-2,5-difeniltetrazol bromida (MTT) nakon 24-satne inkubacije s toksičnom koncentracijom CEES-a $\left(1000 \mu \mathrm{mol} \mathrm{L}^{-1}\right)$. Antioksidansi davani sami u različitim koncentracijama $\left(15 \mu \mathrm{mol} \mathrm{L}-1,30 \mu \mathrm{mol} \mathrm{L}^{-1}\right.$, odnosno $\left.60 \mu \mathrm{mol} \mathrm{L}^{-1}\right)$ nisu smanjili vijabilnost stanica. Dvadesetčetverosatna primjena CEES-a i testiranih antioksidansa pokazala je da samo EB-1 i njegovi analozi EB-2, EB-3 i EB-4 mogu spriječiti smrt stanica, ali ne i stilbenski spojevi. EB-1 i EB-4 pokazali su se najdjelotvornijima u ublažavanju toksičnosti CEES-a u skladu s koncentracijom, dok su se EB-2 i EB-3 pokazali najmanje djelotvornima. Ovdje prikazani podaci upućuju na to da organoselenijevi antioksidansi, a napose EB-4, mogu biti korisni protuotrovi plikavcima.

KLJUČNE RIJEČI: CEES, EB-1, EB-2, EB-3, EB-4, humane stanice epidermoidnog karcinoma, MTTtest, organoselenij, plikavci, protuotrov, pterostilben, resveratrol, vijabilnost stanica

\section{CORRESPONDING AUTHOR:}

Blase Billack

Department of Pharmaceutical Sciences,

St. John's University

8000 Utopia Parkway, Jamaica, NY 11439, USA

E-mail: billackb@stjohns.edu 